\title{
Buddhist Universities in the United States of America
}

Tanya Storch

Correspondence: tstorch@pacific.edu Department of Religious Studies, University of the Pacific, California, USA

\begin{abstract}
This article is written with a purpose to initiate a public discussion of Buddhist-based universities in the united states of America. These universities provide education in liberal arts and professional fields, while employing the time-tested methods of traditional Buddhist pedagogy. Because these universities are generally unknown to the public, I have provided information about their history, academic programs, and the educational success created on their campuses. These universities, in my view, serve as a model of higher education which is successful on many different levels and produces satisfactory results for both those who provide and those who receive the higher education.

Buddhist Dharma has spread in the United States of America in many different ways. One important way in which it has successfully permeated the consciousness of the broader public is through educational institutions. This is consistent with the nature of Buddhism itself. In each country to which it historically spread, it created schools, universities, and various centers for learning, meditation, and moral practicea. In the USA, a great variety of Buddhistbased institutions of learning were created during the last half of the 20th century. These include, but are not limited to kindergartens, elementary and secondary schools, institutes for vocational training, and universities granting professional degrees. In this article, we will investigate one particular type of Buddhist educational institution, which we refer to as a "Buddhist University."
\end{abstract}

\section{What is the Buddhist University and why to study it?}

While the great majority of Buddhist educational institutions specialize in teaching Buddhist philosophy and practice to lay people wishing to develop a Buddhist lifestyle and/or in training monastics wishing to serve as clergy (Diamond Mountain University in Arizona, Won Institute of Graduate Studies in Pennsylvania, Institute of Buddhist Studies in Hawaii, and Dhammakaya Open University in California can serve as examples), some institutions offer Buddhist spiritual and moral training which is combined with professional fields and liberal arts. These can be called Buddhist Universities. This is the definition of a Buddhist University as it has been used throughout this article: a Buddhist University is an institution of higher learning which offers state-accredited degrees in liberal arts and professional fields and employs Buddhist pedagogical principles in education.

There are four Buddhist Universities to which this definition can be applied. These are Naropa University, founded on the principles of Tibetan Buddhism in 1974 by the Lama Chogyam Trungpa ${ }^{\mathrm{b}}$ (located in Boulder, Colorado); the Dharma Realm Buddhist University, founded on the principles of Chinese Buddhism in 1976 by Master Hsuan Hua (located in

(c) 2013 Storch; licensee Springer. This is an Open Access article distributed under the terms of the Creative Commons Attribution License (http://creativecommons.org/licenses/by/2.0), which permits unrestricted use, distribution, and reproduction in any medium, provided the original work is properly cited. 
the City of Ten Thousand Buddhas in Northern California) ${ }^{\text {; }}$; Soka University of America, founded on the principles of Soka Gakkai, Japanese lay Buddhism, in 1987 by Mr. Ikeda Daisaku ${ }^{\mathrm{d}}$ (located in Aliso Viejo in Southern California), and University of the West, formerly known as Hsi Lai University, which was founded on the principles of Taiwanese Buddhism in 1991 by Master Hsing Yun (located in Rosemead, Southern California).

In addition, Maitripa College in Portland, Oregon, which was established in 2005 as a Tibetan Buddhist Theological College, is now applying for regional accreditation as a degree-granting institution. Within a few years, it, too, will become a Buddhist University ${ }^{\mathrm{e}}$.

Thus, four Buddhist Universities currently exist in the USA. The next important issue that needs to be addressed concerns the reasons for studying them. One major reason is that the existence of these universities is generally unknown to the public. Even scholars who specialize in studying American Buddhism and the history of American higher education are either entirely unaware of them or know of only one or two.

Another important reason for studying Buddhist Universities in the USA is their unique position on the map of American higher education. Other religions that are well-known and practiced here, such as Native Shamanism, Hinduism, Jainism, Sikhism, Bahaism, Confucianism, and Daoism, have not created comparable institutions for higher learning, although they have established other types of institutions where these religions are studied. To further this notion of the uniqueness of the American Buddhist University, we must be reminded that the USA has only two Jewish universities and only one Islamic university that are typologically similar to the Buddhist University in that they, too, offer degrees in professional fields and liberal arts while building the entire educational experience on the moral laws and practices of these respective religions. The American Buddhist University must also be recognized as a new global phenomenon because a comparable institution does not exist in other Western countries known for their religious tolerance and political will to experiment with new forms of education, such as Germany, France, Sweden, or the UK.

The last, and possibly most pressing, reason for studying the Buddhist University is the current crisis in American college and university education ${ }^{\mathrm{g}}$. Less than 50\% of students who graduate from American colleges and universities are satisfied with the education they received, while the national dropout rate from graduate education is reaching an alarming $30 \%$. At the same time, research conducted on Buddhist University campuses indicates that the rate of graduation from these universities is close to $90 \%$, and more than $90 \%$ of the students interviewed report to be fully satisfied with the education they have received.

\section{Brief history of the four Buddhist Universities}

\section{Naropa University}

Naropa University was founded in 1974 by Chogyam Trungpa (1939-1987), an exiled Tibetan tulku ${ }^{\mathrm{h}}$, who was a holder of the Kagyu and Nyingma lineages. He arrived in the USA in 1970 and established the Vajradhatu organization three years after. In 1974, he established the Naropa Institute through the Nalanda Foundation, and this served as a preparatory phase for the creation of the university with the same name.

Chogyam Trungpa is considered by some to be a controversial figure. The main reason for that is that he rejected a monastic life-style and actively engaged in secular material life, including smoking, the consumption of alcohol, and marriage. Many of his followers consider these experiences to be Tantric in nature and eventually leading to enlightenment ${ }^{\mathrm{i}}$. Despite the controversy, his role in bringing Buddhist education into 
the Western culture must be considered most significant and can be summarized by the recently spoken words of the $14^{\text {th }}$ Dalai Lama: "His [Lama Trungpa's] was an influential attempt to share some of the insights and benefits of the teachings of Tibetan Buddhism with a modern audience in terms that they could easily understand and put into effect. Exceptional as one of the first Tibetan lamas to become fully assimilated into Western culture, he made a powerful contribution to revealing the Tibetan approach to inner peace in the West $\mathrm{t}^{\mathrm{j}}$.

Naropa was accredited by the North Central Association of Colleges and Schools in 1988, making it the first Buddhist University to receive regional accreditation. The first formal degrees established there were in the areas of Buddhist Studies, Visual Arts, Music, and Psychology. Today, it offers dozens of professional degrees including graduate degrees in Psychology, Education, Environmental Leadership, and Religious Studies ${ }^{\mathrm{k}}$.

Trungpa's fame as a powerful spiritual guru attracted, throughout the 70s and 80s, some of the best poets and musicians of that remarkable epoch. In particular, Alan Ginsburg, John Cage, Anne Waldman, and Diane di Prima are known to be behind the creation of music and literature programs at Naropa University. The Jack Kerouac School of Disembodied Poetics, founded with the most active participation of Alan Ginsberg, is considered to this day to be one of the best places for studying literature in the USA ${ }^{1}$.

John Cobb, a Harvard graduate and a practicing Buddhist, became the second president of the school following Chogyam Trungpa's death ${ }^{m}$. Today, Naropa is under the guidance of Charles Lief, one of the early North American students of Chogyam Trungpa, who helped founding the university in 1974. Charles Lief was serving as chairman of the university's board when he was asked to serve as a president. Based on his inaugural speech given in February of 2013 (it is available online), he is committed to continuing Buddhist-inspired non-sectarian traditions of the Naropa University.

\section{The Dharma Realm Buddhist University}

The Dharma Realm Buddhist University (DRBU) was founded in 1976 by a Chinese Master Hsuan Hua (1918?-1995). According to his biography compiled by Master Hua's close disciples, when he was observing the mourning ritual for his mother, he received a vision of the Sixth Patriarch of the Chan School, who had walked into his hut and encouraged him to go to the West to help people realize their Buddha-nature. In response to this vision, Hsuan Hua moved to Hong Kong in 1949, which also helped him escape persecution in the hands of the Chinese communists. Before moving to, Hong Kong, he trained extensively with the Chan master Xuyun (1840-1959), who bestowed on him the mind-seal transmission in the Weiyang lineage and gave him his Dharma-name Hsuan Hua, which literally means "To Proclaim and Transform" ${ }^{\mathrm{n}}$.

In 1962, Hsuan Hua arrived in San Francisco, CA, and began lecturing in Chinatown ${ }^{\circ}$. In his first years of teaching, he made contacts with many Americans of European descent who wished to study Zen. Several of his disciples who were trained by him in these years have later acquired distinguished positions in the American Zen culture, including the first Abbot of the San Francisco Zen Center, Richard Baker.

In 1963, because of some problems with his American disciples, Hsuan Hua imposed on himself a period of social isolation ${ }^{\mathrm{p}}$. The isolation ended in 1968, when he started actively preaching again and conducting public meditation sessions. One specific aspect of his activities after 1968 involved monastic ordination ceremonies. It is known that, 
in 1976, 1979, 1982, 1989, 1991, and 1992, he conducted full ordinations in Oregon, Washington, and California, in which several hundred people participated, both women and men. Hsuan Hua, unlike the founder of Naropa University, sought to establish a form of Buddhist education in which monastics and lay followers participated on equal grounds, and this approach is still fully present in the DRBU educational programs. In particular, it has a significant number of the monastics on its Board of Trustees as well as among its instructors.

Hsuan Hua strongly believed that translating Buddhist texts from Chinese to English must be a part of Buddhist-based education. He is quoted as saying, "As soon as I became a monk, I looked into why so few people study Buddhism despite its undeniable principles.... I discovered that it was because the disciples of the Buddha did not translate the Buddhist sutras into different [Western] languages ${ }^{\mathrm{q}}$." Consequently, he initiated translation activities in the Buddhist Lecture Hall in San Francisco as early as 1968. In 1973, he established the International Translation Institute on Washington Street in San Francisco, where it successfully functioned until it merged with DRBU in 1977. Today, the Buddhist Text Translation Society exists independently from the University ${ }^{r}$, but a whole set of degrees granted by DRBU are still related to International Translation Institute activities.

Land for the Dharma Realm Buddhist University was purchased by Hsuan Hua's disciples in 1976. Commonly referred to as the City of Ten Thousand Buddhas, it hosts so much more than a typical university campus does. Sitting on 448 acres of groves and meadows in Mendocino, it embraces twenty-five institutional buildings, such as Instilling Goodness Elementary School, Developing Virtue Secondary School, Joyous Giving House for nuns and monks, and Tathagata Monastery, which coexist with fruit orchards, vegetable patches, and a vegetarian restaurant.

\section{Soka University of America}

Soka University was founded on a humanistic educational philosophy developed by an ordinary man who had never joined the ranks of the clergy. Tsunesaburo Makiguchi (1871-1944), a schoolteacher in Japan, was a devout lay Buddhist and, during the preWorld War II period (in 1930), he founded Soka Gakkai - a public foundation committed to promoting true and valuable knowledge to young Japanese. Makiguchi's approach opposed nationalistic and chauvinistic state propaganda forcing the children of Japan to worship the Emperor as a living god and preparing the country for the upcoming imperial aggression against the USA and other nations. Mr. Makiguchi was arrested for his ideas and thrown into prison where he died just a year before the collapse of the regime that ordered his imprisonment and torture ${ }^{\mathrm{s}}$.

After the end of the war, Soka Gakkai became a powerful cultural and educational organization. From less than 3,000 members remaining from the pre-war organization it was quickly built to 750,000 followers by the end of the 1950 s. The organization began to play a particularly important role after 1975, when Soka Gakkai International (SGI) was established by Mr. Ikeda Daisaku, who became the first president of this international organization; its originally declared goals were the support and promotion of Nichiren Buddhism and the establishment of a global Buddhist movement for peace, education, and cultural exchange.

Nichiren Buddhism is considered to be controversial by many scholars and practitioners of other forms of Buddhism. Its origins go back to the life and teachings of a 
medieval Japanese monk, Nichiren (1222-1282), who openly condemned other schools of Buddhism and conducted the so-called "confrontational conversions." He is known to have called the followers of Zen Buddhism as "devils," and promising to the followers of Pure Land Buddhism that they would end in hell instead of the Pure Land ${ }^{t}$. Understandably, such derogative evaluations of other schools of Buddhism did not provide for a peaceful reception of his teachings. Nonetheless, Nichiren played a crucial role in the history of Japanese and global Buddhism because he made Buddhist practices entirely democratic and open and accessible to every person. He taught that all living beings are equally endowed with the potential for enlightenment, which they can reach within this lifetime. According to his views, simply by chanting the mantra, "Nam myoho renge kyo" (O, Blessed be the Lotus Sutra), by gaining clarity of mind, and by understanding the interconnectedness of all life, each person can reach complete liberation from the laws of karma ${ }^{\mathrm{u}}$.

Mr. Ikeda Daisaku, who is still alive, was born in 1928 to a family of seaweed farmers near Tokyo. He suffered from tuberculosis as a child, and doctors made a prediction that he would not live beyond age 30 . The Ikeda family barely survived the hardships of the war, and soon after the war ended, young Daisaku became interested in the Buddhist philosophy of Nichiren. In particular, he developed an admiration for, and became a close disciple of Josei Toda (1900-1958), the president of the Soka Gakkai organization at that time. Mr. Toda taught him literature, history, chemistry, physics, political science, and law, all the while educating him in the Nichiren Buddhist ideology. After the death of Josei Toda, Ikeda Daisaku committed himself to spreading Toda's and Nichiren's teachings throughout the entire human community.

In fulfillment of this commitment, he actively engaged in creating the Soka University of America. In February 1987, the first undergraduate campus of Soka University was dedicated in Calabasas, California; and in 1994, the graduate school opened, offering M.A. degrees in Second and Foreign Language Education. In 1995, Soka University acquired a 103acre piece of land in Aliso Viejo and opened a new campus there in 2001. It received regional accreditation by the Western Association of Schools and Colleges (WASC) in $2005^{\mathrm{v}}$.

\section{University of the west (formerly known as the Hsi Lai University)}

The University of the West was founded on the principles of Taiwanese Buddhism, known as Humanistic Buddhism, by Venerable Hsing Yun. Hsing Yun was born in 1927 and is alive today, although his health is deteriorating rapidly. He is the founder of the Foguangshan Buddhist order in Taiwan and, affiliated with it, the Buddha's Light International Association, which is currently one of the largest Buddhist organizations in the world.

Hsing Yun became a novice at age 12 and was fully ordained at 14 . He is the $48^{\text {th }}$ generation lineage holder in the Linji (Rinzai) tradition. When he was young and still lived in continental China, he attended a Buddhist college, after which he became the principal of an elementary school near Nanjing. Because of the pressures of a civil war started by revolution, he was forced to move to Taiwan in 1949. There, he popularized Buddhist philosophy and education by writing and publishing his own books and providing opportunities for other Buddhism-based authors. Throughout the 1950s and 60s, he established schools in which education in language, science and history was 
combined with Buddhist practices and ethical teachings. Eventually, he established a new tradition in Chinese Buddhism known today as Humanistic Buddhism. This Buddhist movement uses the international Taiwanese Mahayana Buddhist monastic order, Foguangshan, as a platform for modernizing Buddhist ideologies and practices around the world (including in continental China), so that these become easily available to ordinary people globally. Because of this, Master Hsing Yun is often referred to as a forefront leader in the global modernization of Buddhism ${ }^{\mathrm{w}}$.

Hsing Yun was unable to return to continental China for many years after his escape to Taiwan. In immigration, he received the sad news that his teacher had been killed and his college had been destroyed by the Red Guards during the Cultural Revolution. His trips to the People's Republic of China (PRC) became possible only in the 1980s. When he returned, he immediately took care of the restoration of the college he had attended as a youth.

In the USA, Hsing Yun established more than twenty large temples and education/ missionary centers affiliated with the Foguangshan. The largest among them is the Hsi Lai Temple in Los Angeles, founded in 1967. Construction of this large temple complex (more than twenty acres in size) was completed only in 1988, as many delays happened in the construction process because of cultural resentment and legal opposition from local residents ${ }^{\mathrm{x}}$. Three years after the temple was finally opened, a Buddhist-based university bearing the same name as the temple itself -- Hsi Lai University - offered its programs to local and international students. It was renamed as the University of the West in 2008 to more fully represent the university's mission -- spreading Dharma from East to West.

\section{Educational programs offered by the Buddhist Universities}

Before we proceed to explaining about the specific educational programs provided by the Buddhist Universities, we need to understand that these universities do not merely provide, but publicly advertise, professional and liberal arts training deeply rooted in philosophical and moral principles of Buddhism. Below are some of the quotes from their online mission statements and promotional brochures.

"Naropa recognizes the inherent goodness and wisdom of each human being. It educates the whole person, cultivating academic excellence and contemplative insight in order to infuse knowledge with wisdom. The university nurtures in its students lifelong joy in learning, a critical intellect, the sense of purpose that accompanies compassionate service to the world, and the openness and equanimity that arise from authentic insight and self-understanding ${ }^{\mathrm{y}}$.

Dharma Realm Buddhist University describes its educational goals in this way: "Dharma Realm Buddhist University does not merely transmit academic knowledge. It emphasizes a foundation in virtue, which expands into the study of how to help all people and living beings return to their inherent nature. Thus, Dharma Realm Buddhist University advocates a spirit of shared inquiry and free exchange of ideas..." In another place on the University website, we read, "Faculty and students alike strive to exemplify scholarship and character, serious study and solid practice. Intellectual inquiry proceeds, side-by-side, with spiritual self-cultivation, so that the 'classroom' is inspired by the contemplative life... This university exists to promote and support the universal human capacity for goodness and wisdom; its contemplative atmosphere and 
flexible programs offer people a chance to pursue their own spiritual growth and inner enrichment".

The University of the West describes the form of education it provides in a similar way. On its website we read that it educates "a whole person in a context formed by Buddhist wisdom and values" by instilling in its students values of "creative problemsolving, moral and cultural discernment, and personal and social responsibility," and that it promotes "Buddhist inspired contemplative education" in which students are encouraged to "live with presence, purpose, and wisdom".

Soka University presents its Buddhist values in education in a less prominent way than the other three Universities. This more subtle approach is due to the lay origins of Soka Gakkai, the Buddhist organization that established this university; lay practitioners usually place less emphasis on intensive personal discipline and the consistent cultivation of moral virtues. Another reason for their subdued dissemination of Buddhistbased goals in education may lie in the difficult past that Soka Gakkai experienced in Southern California during the $70 \mathrm{~s}$ and $80 \mathrm{~s}^{\mathrm{z}}$. Still, we can identify an educational philosophy similar to that underscored by the other Buddhist Universities. For example, Soka's online mission statement says that it is "founded on the Buddhist principles of peace, human rights, and the sanctity of life." Further on their website we read that Soka teaches all students how to be "philosophers and world citizens" and live a "contributive life." Other education mottos speak of fostering love for humankind, bringing peace to the world, creating peaceful coexistence between nature and human beings, and creating a humanistic environment in all societies.

Turning to specific degrees the Buddhist Universities offer, Naropa grants a B.A. in Contemplative Psychology, Early Childhood Education, Environmental Studies, Interdisciplinary Studies, Music, Peace Studies, Religious Studies, Traditional Eastern Arts, Visual Arts, Writing and Literature, and Fine Arts and Performance. It grants a M.A. in Art Therapy, Contemplative Education, Contemplative Psychotherapy, Environmental Leadership, Religious Studies, Somatic Counseling Psychology, and Transpersonal Psychology, and a Master of Divinity.

DRBU provides a B.A. in Buddhist Study and Practice, Translation and Language Studies, and Chinese Studies. Its M.A. degrees are in Buddhist Study and Practice, Translation and Language Studies, and Buddhist Education.

Soka University of America offers a B.A. in Liberal Arts with concentrations in Environmental Studies, Humanities, International Studies, and Social and Behavioral Sciences. It also has a Teaching Japanese as a Foreign Language certificate program which allows its recipients to teach Japanese in high schools and community colleges.

The University of the West provides a B.A. in Business Administration, Accounting, Computer Information Systems, International Business Marketing, Psychology, and English; a M.A. in Computer Information Systems, Finance, International Business, Psychology, Nonprofit Organization Management; an Executive Master of Business Administration (EMBA), Religious Studies, and a Master of Divinity.

\section{Buddhist pedagogy}

What makes the educational experience at Buddhist Universities unique cannot be explained merely by the professional degrees they provide. What makes them so different from the experience at hundreds of other colleges and universities across the USA 
is that the education in professional fields and liberal arts is built on principles of Buddhist pedagogy. This pedagogy has been tested by thousands of years of history in many different social and cultural environments and now is being applied within American culture. The topic of Buddhist-based education is extremely vast, and here, we are not going to discuss it. Instead, we will focus on the Buddhist-inspired pedagogical principles followed in personal and academic lives of the faculty, students, staff, and administration, which we had a chance to observe and investigate during our fieldwork on Buddhist campuses.

\section{Respect for All life}

The first principle that appears to be the most crucial in Buddhist pedagogy is Respect for All Life. Buddhism emphasizes the notion that the only true foundation for all learning is respect for all life. According to this, a student can never become a good teacher, engineer, accountant, doctor, journalist, and so on, unless she or he has understood and begun regularly practicing "no-harm" and "loving-compassion" in terms of their behavior towards all living beings.

This approach to life in all the forms of activities is visible when Buddhist University campuses are explored. As soon as one begins to walk, there is a sense of having stepped into an environment which is different from that of most colleges and universities. Not only are the environs clean, beautiful, and harmoniously organized, but one finds oneself surrounded by an unusual silence and sounds of peace. One can actually hear nature, such as birds, waterfalls, and the rustling of leaves because they appear against the background of an ever present, soothing silence. The sounds of human activities are gentle and conducted with awareness of the presence of others. In the dining halls and lounges, loud sounds of television are absent. There are no disruptive noises from leaf blowers. Nor will we hear people speaking in loud and angry voices on their mobile phones. People on Buddhist campuses are polite, and they immediately attend to the needs of a stranger. Students or faculty members will immediately change the direction they are going to lead visitors to the building they are looking for.

Respect for all life is evident in the environmental protection programs adopted by all Buddhist Universities, as well as in their active support of animal life and widely followed reuse and recycling plans. Vegetarianism is strictly enforced on the campus of DRBU. The University of the West used to serve only vegetarian meals, but now offers a meat option for non-vegetarians. Naropa and Soka allow meat consumption (which is consistent with the traditional practices of Tibetan and Nichiren Buddhism), but educate students about the benefits of vegetarianism for human health, the environment, and spiritual progress. At Naropa and Soka, vegetarian options are always available. Practice of mindful eating is only now beginning to percolate spirituality and wellness consciousness of the Americans. At the Buddhist Universities it has already become a norm ${ }^{\text {aa }}$.

Some practical expressions of environmental protection at Buddhist Universities are simple steps such as giving each student a free bicycle and free bus pass. There are communally shared cars. This approach minimizes the parking space on campus, which, in turn, brings a cleaner environment. On all Buddhist campuses, plastic, glass, paper, aluminum, food leftovers, and green waste are collected in separate containers and recycled. 
Students are educated about recycling their natural talents and time, as well. The best example of this is found at Naropa University. Near the cafeteria, there is a big bulletin board where students post announcements, which read like this: "I would like to exchange a gift of picking up eatable mushrooms for a gift of knowing how to keep my room always clean and organized (worth 50 karmic points)," or "I exchange lessons of French (worth 20 karmic points each) for help with Biology." In the fall of 2010 (during our visit to campus), there were fifty announcements of this sort. Naropa students, who are encouraged by their professors to avoid waste of any kind, have also designed a storage unit (open for the public) to which they bring things they no longer need. They bring desk lamps, blankets, frying pans, forks, etc., and place them on the shelves inside the storage unit, and then students, faculty, staff, administration, etc., can come and take them free of charge. When they need them no longer, they bring them back to the storage, and the cycle continues ${ }^{\mathrm{ab}}$.

\section{Right motivation for receiving education}

Another important principle of Buddhist pedagogy is Right Motivation for Receiving Education. It starts from administration and faculty affirming that learning is an individual experience and everyone learns differently. Before and after enrollment, students meet with their counselors, who help them discover their natural gifts and the spiritual purpose and meaning of their life. Students are taught that the right motivation for success in education and career must rise from their own heart and mind. By following this principle, students at Buddhist Universities do not measure their success in terms of the "money power" and status they will acquire after graduation; rather, they see their years in college as the beginning of a lifelong process of self-improvement and mastering those virtues and skills with which they will be able to help the planet and all living beings.

Equanimity is crucial to developing right motivation for education; this is well demonstrated by Soka University of America. On its campus, we do not find parking spaces designating social status; there are no administration buildings to shelter decisionmakers from the rest of the university; furthermore, all offices, from the dean's to the janitor's, are the same size $\mathrm{ac}^{\mathrm{ac}}$.

Competition is not encouraged at any of the Buddhist Universities; competition is transformed into cooperation. A distinct aspect of this non-competitive pedagogy is that grades, by themselves, are not as important as the internal commitment to learning and becoming a better person. Equal respect is shown by the faculty and administration toward a slow learner and a fast learner, toward a student who easily earns high scores and the one who fails on some tests but is willing to improve.

Mindfulness accompanies all procedures taking place in Buddhist education. This is exemplified in the decision to take a heuristic approach to measuring students' progress. Sometimes, students receive detailed letters from a professor (describing their progress and making recommendations for further improvement) as a sign that they have earned a sufficient grade; sometimes, students who excel in taking tests are assigned to work with the students who find it difficult to prepare for them, and they work together the entire semester until student-mentor and student-trainee create satisfactory results; sometimes, students conduct their own examinations and professors incorporate the grades given by the students into the final grades ${ }^{\mathrm{ad}}$. According to our 
research, a substantial improvement in students' performance must be credited to this heuristic approach as students learn in a stress-free environment and deeply care about the process and results of their learning.

A large component of what is called right motivation for learning is motivation by compassion for all living beings, which includes all of humanity. This motivation, one student said, "leads to developing a good discipline and long-lasting work habits." She also added that "the examples of Buddhist nuns and monks are very useful in this respect." Monastics are present on two campuses, DRBU and UWest, where they serve as role models in terms of motivating students to develop "the right way" for success. A student from UWest summarized this by saying, "We observe how nuns and monks dedicate their lives to serving other living beings and we cannot help but start asking questions about our own commitment and dedication. These are not necessarily religious views we are asking about, but simply the question of the meaning of it all, such as going to college, receiving a degree, and so on ${ }^{\text {ae" }}$.

\section{Learning for the present, Not for some distant future}

"Learning for the present," means that boundaries between classroom and real life learning are practically nonexistent. Students are expected to learn from everything that happens in their lives, not only from what they learn in their classes. And vice versa, students are expected to use in their daily lives all the knowledge they gain through their formal study.

When students enter the classroom they are invited to meditate and reflect on the state of their mind and the purpose for receiving education ${ }^{\text {ef }}$. Professors often ask them how they apply knowledge they have acquired through their study. The subject may be business, computer engineering, or English literature. The question leads to the realization that the most important thing in learning is to know how knowledge can be applied to real life. One student told a professor that he had called his friend at another university and shared with him a particular program he learned two days ago. This friend was surprised and greatly appreciated the call, and he called him back to share something new he had learned. Another student shared that he had gone to a nearby business and offered help with bookkeeping. The offer was accepted with gratitude, and a real accounting practice began with a promise to become partners in business. Yet another student spent an afternoon at a local vegetarian restaurant, where he gave a free evaluation of resources management. Based on what he learned in his program, he was able to give useful advice and was invited to eat for free for a whole week!

Continuity of educational experience must extend from one moment to another. There is always something new to learn. This is the advice given to students by faculty and administrators who share living space with the students. Even as they take food in the dining hall they are learning what it means to be a human being. A senior nun has difficulty standing in line for lunch. This is a call for compassion. Someone asks her what she would like to eat and then serves her the requested food. Students have just learned a lesson that, when they feel sorry for someone else's suffering, there is a way to ease the pain through appropriate compassionate action. As students go about choosing their own food for lunch, they learn awareness of their physiological needs because so many people around them are already mindful of what they eat and how much they need and this shows in their behavior. There is always something new to watch 
and learn from! Food and drinks are almost never wasted in this context of personal awareness of one's needs.

At the Buddhist Universities, students have an opportunity to actively participate in growing, preparing, and serving their own food, which creates yet another vital connection between learning and practicing in the present moment instead of for some distant future. At DRBU, students grow the vegetables and fruit they later eat in the dining hall or take home to share with others. Here, students work in orchards and gardens so large that they provide nearly half of all the produce needed for the university's annual consumption. Naropa students use a greenhouse located a few steps away from the cafeteria and, if they need more fresh food, they can use the agricultural space at the nearby University of Colorado.

Students continue learning and practicing professional and moral knowledge after classes are over. They continue being compassionate and respectful of all life because, in the dormitories, they do not smoke, do not drink alcohol, and do not play loud music. At the University of the West and DRBU, monastics reside in the vicinity of the students, and this provides for a greater measure of peace and mindfulness across the halls. Crime does not thrive on the Buddhist University campuses as it does on the campuses of so many American colleges. Attention is paid by all members of the community to how people act and interact. A janitor may follow a student to the classroom to tell her that she has left a mess in the bathroom, and the student usually goes back to take care of the situation. Everyone feels responsible for the clean environment. This behavior builds up and continues when students leave the campus ${ }^{\mathrm{ag}}$.

Learning does not end when the students leave their campuses and mingle with other people. Naropa students made a decision to share with local farmers the composted materials from their campus. The farmers, in turn, decided to share their pears, apples, and other fruit, all of which must be picked by students from the trees on the property. Students of UWest volunteer at the Buddhist Memorial Complex affiliated with the Hsi Lai Temple. By helping families who have lost loved ones, they also learn about human psychology and behavior in real time; while Soka students take their math and language skills outside of the classroom by educating members of minority communities and UWest students teach local residents how to prepare taxes. UWest, Soka, and DRBU students majoring in English often create partnerships with local kindergartens and elementary schools and volunteer as tutors to those children whose families do not speak English.

When the whole system of education is organized in such a way that every piece of information is learned for the sake of helping others, the learning process acquires a different meaning. When students see how they can make a difference in people's lives, their enthusiasm for learning grows exponentially.

\section{Conclusion}

This article is meant to initiate a public discussion of the pedagogy of Buddhist Universities in the United States of America. In my forthcoming book, Buddhist-inspired Universities in the USA, I investigate in further depth issues pertaining to this subject, such as the results of comparative institutional data analysis, comparisons between Buddhist Universities and other institutions of higher learning that are equally based on moral virtues (with Jewish, Quaker, and Islamic Universities used as examples), and the 
potential danger of associating all moral education with specific religious practices. With American higher education in crisis, the many aspects of Buddhist-based education in America that make it so successful need to be researched and understood, for potential application to other colleges and universities in the USA.

Because Buddhist Universities are generally unknown to the public, I have provided information about these universities' histories, academic programs, and the educational success created on their campuses. Buddhist Dharma has a historical tradition of success in higher education, having built universities everywhere it has spread. Buddhist Universities provide a model of higher education which is successful on many different levels and produces satisfactory results for both those who provide and those who receive higher education.

Education based on right motivations and moral virtues is not unique to Buddhism. Because of space limitations, research material from American Jewish, Quaker, and Islamic universities could not be included, but from a preliminary analysis of institutional data collected at these universities, we know that their students, faculty, and administrations also report levels of satisfaction with learning and teaching experiences that are higher than the national average. It seems, therefore, that a main problem with most American institutions of higher learning lies in their lack of awareness regarding the effectiveness of integrating value-based learning and practice of basic human morality into the structure of general pedagogy in higher education. By focusing on the spread of Buddhist Dharma in North America, and the corollary alternate educational infrastructure that has followed in its wake, we may see, in a more clear light, one of our biggest social challenges today, and effective methods for addressing it.

\section{Endnotes}

aThe oldest known university in Asia, and possibly in the world, was founded by Buddhist scholars. Quoting Johan Elverskog, "The Nalanda university founded in northeast India in the early 4th century became the premier institution of higher learning in Asia and, much like leading universities today, Nalanda had a world-renowned faculty working on the cutting edge of the theoretical sciences and a student body drawn from across the Buddhist world." See Buddhism and Islam on the Silk Road (Philadelphia: University of Pennsylvania Press, 2010): 1.

${ }^{b}$ Biographies of the founders of Buddhist universities are detailed in the following section of this article.

'This university used to have state accreditations, but lost them due to the stricter requirements imposed during the 1990s. It is currently granting degrees through association with the Institute for World Religions.

${ }^{\mathrm{d}}$ A brief history of Soka Gakkai International will be discussed along with the biography of Ikeda Daisaku.

${ }^{\mathrm{e}}$ Maitripa College is affiliated with the Foundation for Preservation of the Mahayana Traditions. Lharampa Geshe and Yangsi Rinpoche are credited as its historical founders while its current Spiritual Director is Rinpoche Thubten Zopa. In the last two years, the College's most prominent degrees were the M.A. in Buddhist Studies and Master of Divinity.

${ }^{f}$ Yeshiva University was founded in 1886 in New York; today, it combines contemporary academic education with the teachings of the Torah. In 2007, the American Jewish 
University (AJU) was created as a result of merging the University of Judaism with Brandeis-Bardin College. It now offers degrees in Bioethics, Psychology, Liberal Studies, Business, Communication, Political Science, and Jewish Studies. Islamic American University (IAU) in Southfield, Michigan, offers the spiritual teachings of Islam along with degrees in Liberal Arts and several professional fields.

${ }^{\mathrm{g}}$ According to a poll conducted by Time Magazine and the Carnegie Corporation, $89 \%$ of American adults think that higher education is in crisis; $54 \%$ say that it is moving in a wrong direction. According to the same poll, $96 \%$ of senior higher education administrators express the opinion that their sector of education is in crisis, while $40 \%$ of them indicate the crisis is severe. See www.livingstondaily.com (retrieved on January 15, 2013). Also see Gene A. Budwig (2013) "Beating America's College Crisis," in the online public forum, "Colleges in Crisis," at http://harvardmagazine.com.

${ }^{\mathrm{h}}$ Tulku denotes the high lama who remembers his previous reincarnations. About Chogyam Trungpa remembering his past lives, see Fabrice Midal, Chogyam Trungpa: His Life and Vision (Boston and London: Shambala, 2012): 32-34. The founder of the Naropa University is also referred to as Trungpa Rinpoche.

'Trungpa Rinpoche's non-orthodox approach to Buddhist education, and reasons for giving up his monastic status are expressed in his autobiography, Born in Tibet, and other writings. We specifically recommend: Cutting through Spiritual Materialism, The Myth of Freedom, and You Might Be Tired of the Seat that You Deserve. Trungpa Rinpoche's life is described in many publications, including Fabrice Midal, Chogyam Trungpa: His Life and Vision (Boston: Shambhala Publications, 2004) and Jeremy Hayward, Warrior-King of Shambhala: Remembering Chogyam Trungpa (Boston: Wisdom Publications, 2008).

'See the Dalai Lama's introduction to (ed.) Fabrice Midal, Recalling Chogyam Trungpa (Boston: Shambhala Publications, 2005): IX-X.

${ }^{\mathrm{k}}$ Specific degrees granted by each Buddhist University are analyzed in the following section of this article.

'Recollections of the school's history can be found in Sam Kashner's When I was Cool: My Life at the Jack Kerouac School. (New York: Harper Collins, 2004).

${ }^{\mathrm{m}}$ The first president, active during the lifetime of Trungpa Rinpoche, was Barbara Dilley.

${ }^{n}$ Most complete biography of Master Hsuan Hua can be found in two-volume collection of various biographical data, photo-materials, and his lectures and speeches, which was put together shortly after his death by his students. See In Memory of the Venerable Master Hsuan Hua. Burlingame, CA: Buddhist Text Translation Society and Dharma Realm Buddhist University, 1995-1996.

${ }^{\circ}$ The place was originally referred to as the Buddhist Lecture Hall; it is known today as the Dharma Realm Buddhist Association.

${ }^{\mathrm{P}}$ The exact nature of the problems Master Hua had encountered with his European American disciples is nearly impossible to investigate because the answers we received from his still living followers were evasive. According to one disciple, Ronald Epstein, he went into seclusion because of his students "disrespectful behavior toward the Dharma." See his In Memory of the Venerable Master Hsuan Hua (Burlingame, CA: Buddhist Text Translation Society, 1995): 59-68, for a fuller biographic account. 
${ }^{\mathrm{q}}$ Out of the Ground It Emerges: Wonderful Enlightenment Mountain. Celebrating 40 Years of Dharma in the West as Transmitted by the Venerable Master Hsuan Hua (Burlingame, CA: Buddhist Text Translation Society, 2001): 76.

${ }^{\mathrm{r}}$ It is now located in Burlingame, CA.

${ }^{\mathrm{s}}$ About his contribution to the Buddhist-based education see Dilma de Melo Silva, "Makiguchi Project in Action - Enhancing Education for Peace," Journal of Oriental Studies 10 Special Issue (2000): 62-93; Namrata Sharma, Value Creators in Education (New Delhi: Regency Publications, 1999), and Dayle Bethel, Education for Creative Living: Ideas and Proposals of Tsunesaburo Makiguchi (Iowa: Iowa State University Press, 1989).

${ }^{t}$ See Donald Mitchell, Buddhism (Oxford: Oxford University Press, 2008): 303.

"See Daniel A Metraux, "The Soka Gakkai: Buddhism and the Creation of a Harmonious and Peaceful Society," In (eds.) Christopher Queen and Sallie King, Engaged Buddhism: Buddhist Liberation Movements in Asia (New York: SUNY Press, 1996) for a positive evaluation of Nichiren's teachings, and Adam Gamble and Takesato Watanabe, A Public Betrayed: An Inside Look at Japanese Media Atrocities and Their Warnings to the West (Washington, DC: Regnery Publishing, 2004) for criticism of some of their negative aspects.

${ }^{\mathrm{v}}$ For more details, see Richard Walker, "Soka University of America's $10^{\text {th }}$ Anniversary," SGI Quarterly (April 2013): 1-3; and John Pulley, "Soka U. Tries to Invent College," The Chronicle of Higher Education (January 2001): 19.

${ }^{\text {w} A ~ v e r y ~ d e t a i l e d ~ b i o g r a p h y ~ o f ~ H s i n g ~ Y u n ~ i s ~ F u ~ Z h i y i n g, ~ B r i g h t ~ S t a r, ~ L u m i n o u s ~ C l o u d: ~}$ The Life of a Simple Monk (Hacienda Heights: Buddha's Light Publishing, 2008). For a more critical approach to Foguangshan, see Stuart Chandler's Establishing a Pure Land on Earth (Honolulu: University of Hawaii Press, 2004).

${ }^{x}$ Irene Lin detailed the story of cultural bigotry taking place during construction of this temple in "Journey to the Far West," in (ed.) Tanya Storch, Religions and Missionaries in the Pacific (Aldershot, UK: Ashgate Publishing Ltd., 2006): 383-408.

${ }^{\mathrm{y}}$ University website.

${ }^{\mathrm{z}}$ For instance, James William Coleman characterized the situation by saying, "Soka Gakkai has been known to pursue an aggressive policy in proselytization known by the descriptive Japanese name, shakubuku, which translates as 'break and subdue'." See his chapter, "The New Buddhism: Some Empirical Findings," in (eds.) Duncan Ryukan Williams and Christopher Queen, American Buddhism: Methods and Findings in Recent Scholarship (Richmond: Curzon Press, 1999): 91-99. In response to resentment from the public, the organization changed its style of preaching during the late 90s, and as a result, accepted a separation from the Nichiren clergy. As Robert Kisala explained, "they got rid of monks' control and outdated exclusivism." This decision led to the loss of religious privileges, such as monk's blessings at the funerals, or obtaining of the monks' handwritten certificates (daihonzon). See "Soka Gakkai: Searching for the Mainstream," in (eds.) James Lewis and Jesper Petersen, Controversial New Religions (Oxford: Oxford University Press, 2004): 149-150.

${ }^{\mathrm{aa}}$ Fresh online published studies on the psychological and medical benefits of mindful eating are overwhelming. Here are just a few examples: Evann Gastaldo, "New on the Menu: Mindful Eating," Newser (February 8, 2012); Jeff Gordiner, "Mindful Eating as Food for Thought," The New York Times (February 7, 2012); and Phra Paisal Visalo, "The Art of Eating the Buddhist Way," Visalo (March 10, 2013). 
${ }^{\mathrm{ab}}$ We are particularly impressed by this simple way of saving material and human resources because, on and around the campus of the university where we serve, each new academic year brings piles of garbage that used to be student furniture and other reusable possessions.

${ }^{\text {ac } J o h n ~ P u l l e y ~(o p . ~ c i t .) . ~}$

${ }^{\text {ad }}$ An interesting experience, in this respect, is ongoing at Naropa University. Read about the "Warrior Exam" in Dale Asrael, "Love of Wisdom Puts You on the Spot: The Warrior Exam," in (eds.) Judith Simmer-Brown and Fran Grace, Meditation and the Classroom (Albany: State University of New York Press, 2011): 187-194.

${ }^{\mathrm{ae}} \mathrm{A}$ valuable introduction of this method to a larger academic audience is in Vaishali Mamgain's article, "Ethical Consciousness in the Classroom: How Buddhist Practices Can Develop Empathy and Compassion," Journal of Transformative Education 1 (2010): 22-41. We now have the evidence that compassion-meditation can be practiced for the sake of greater psychological stability at a workplace. See the results of a study published by Stefan Hofmann, et al., "Loving-Kindness and Compassion Meditation: Potential for Psychological Interventions," Clinical Psychology Review 7 (2011): 1126-1132.

${ }^{\text {af } J u d i t h ~ S i m m e r-B r o w n ~ d i s c u s s e s ~ s i g n i f i c a n t ~ p e d a g o g i c a l ~ p o t e n t i a l ~ o f ~ m e d i t a t i o n ~ i n ~}$ the classroom: "The Question is the Answer: Naropa University's Contemplative Pedagogy, Religion and Education (Summer 2009); see also a collection of papers in (ed.) Simmer-Brown and Fran Grace, Meditation and the Classroom. (Albany: SUNY Press, 2011). Meditation's effects on learning are becoming more widely recognized even outside of Buddhist-based education. A recent report was made for the business community in Jeff Stone, "World's Happiest Man, Matthew Ricard, Credits Meditation for Learning and Memory Abilities," International Business Times (October 2012): 29.

${ }^{\mathrm{ag}} \mathrm{A}$ real story: a student from UWest picked up trash on a street in L.A., and a stranger from the other side of the street came to him to thank him.

\section{Competing interests}

The author declares that she has no competing interests.

Received: 14 October 2013 Accepted: 15 October 2013

Published: 12 December 2013

\section{References}

Bethel, D. 1989. Education for Creative Living: Ideas and Proposals of Tsunesaburo Makiguchi. lowa: lowa State University Press.

Buddhist Translation Society. 2001. Out of the Ground It Emerges: Celebrating 40 Years of Dharma in the West as Transmitted by the Venerable Master Hsuan Hua. Burlingame CA: Buddhist Text Translation Society.

Budwig, G. 2013. Beating America's College Crisis. http://harvardmagazine.com.

Chandler, S. 2004. Establishing a Pure Land on Earth. Honolulu: University of Hawaii Press.

James William, C. 1999. The New Buddhism: Some Empirical Findings. In American Buddhism: Methods and Findings in Recent Scholarship, ed. W Duncan and Q Christopher. Richmond: Curzon Press.

Dalai, L. 2005. A Message From His Holiness the Fourteenth Dalai Lama. In Recalling Chogyam Trungpa, ed. M Fabrice. Boston: Shambhala Publications.

Elverskog, J. 2010. Buddhism and Islam on the Silk Road. Philadelphia: University of Pennsylvania Press.

Epstein, R. 1995. In Memory of the Venerable Master Hsuan Hua. Burlingame CA: Buddhist Text Translation Society. Fu, Z. 2008. Bright Star, Luminous Cloud: The Life of a Simple Monk. Hacienda Heights: Buddha's Light Publishing.

Gamble, A, and T Watanabe. 2004. A Public Betrayed: An Inside Look at Japanese Media Atrocities and Their Warnings to the West. Washington DC: Regnery Publishing.

Gastaldo, E. 2012. New on the Menu: Mindful Eating. In Newser. Web. February 8.

Gordiner, J. 2012. Mindful Eating as Food for Thought. The New York Times. Web. February 7.

Hayward, J. 2008. Warrior-King of Shambhala: Remembering Chogyam Trungpa. Boston: Wisdom Publications.

Hofmann, S, et al. 2011. Loving-Kindness and Compassion Meditation: Potential for Psychological Interventions. Clin Psychol Rev 7.

Kashner, S. 2004. When I was Cool: My Life at the Jack Kerouac School. New York: Harper Collins.

Kisala, R. 2004. Soka Gakkai: Searching for the Mainstream. In Controversial New Religions, ed. L James and P Jesper. Oxford: Oxford University Press. 
Lin, I. 2006. Journey to the Far West. In Religions and Missionaries in the Pacific Aldershot, ed. S Tanya. UK: Ashgate Publishing Ltd.

Mamgain, V. 2010. Ethical Consciousness in the Classroom: How Buddhist Practices Can Develop Empathy and Compassion. Journal of Transformative Education 1.

de Melo Silva, D. 2000. Makiguchi Project in Action: Enhancing Education for Peace. Journal of Oriental Studies Special Issue: 10.

Metraux, D. 1996. The Soka Gakkai: Buddhism and the Creation of a Harmonious and Peaceful Society. In Engaged Buddhism: Buddhist Liberation Movements in Asia, ed. Q Christopher and K Sallie. New York: SUNY Press.

Midal, F. 2004. Chogyam Trungpa: His Life and Vision. Boston: Shambhala Publications.

Mitchell, D. 2008. Buddhism. Oxford: Oxford University Press.

Simmer-Brown, J, and G Fran (eds.). 2011. Meditation and the Classroom. Albany: SUNY Press.

Simmer-Brown, J. 2009. "The Question is the Answer: Naropa University's Contemplative Pedagogy,". Religion and Education (Summer Issue).

Stone, J. 2012. World's Happiest Man Matthew Ricard Credits Meditation for Learning and Memory Abilities,". International Business Times. October Issue.

Trungpa, C. 2000. Born in Tibet. Boston: Shambhala Publications.

Visalo Phra Paisal. 2013. The Art of Eating the Buddhist Way. Visalo. Web. March 10.

doi:10.1186/2196-8802-1-4

Cite this article as: Storch: Buddhist Universities in the United States of America. International Journal of Dharma Studies 2013 1:4.

Submit your manuscript to a SpringerOpen ${ }^{\circ}$ journal and benefit from:

- Convenient online submission

- Rigorous peer review

- Immediate publication on acceptance

- Open access: articles freely available online

- High visibility within the field

- Retaining the copyright to your article

Submit your next manuscript at $>$ springeropen.com 